\title{
APLIKASI MODEL PEMBELAJARAN OME-AKE DALAM PENINGKATAN KEAKTIFAN BELAJAR PESERTA DIDIK DI MTS. AL-ARIEF JATE GILI GENTING SUMENEP
}

\author{
Achmad Abdul Munif \\ abdmunif@gmail.com \\ STIT al Urwatul Wutsqo Jombang \\ Mokh.Fakhruddin. S \\ Guru PAI SMAN Plandaan Jombang \\ Tatak Winarta \\ tatakwinarta@yahoo.com \\ STIT al Urwatul Wutsqo Jombang
}

\begin{abstract}
This study began with the OME AKE learning model applied at MTs Al-Arief Jati Gili Genting Sumenep Madura, students were active in learning, even academic and non-academic achievements of students were very good. The study of this research is the application of the OME AKE learning model in MTs. Al-Arief Jate Gili Genteng Sumenep. This study uses a qualitative approach to the type of field research (field research). Steps The application of the OME AKE learning model in increasing the learning activeness of students at MTs Al-Arief Jate-Gili Genting-Sumenep runs according to the educational process standards. In learning, it refers to the syntax that is determined, with the first steps being learning orientation, modeling, topic exploration, analysis and problem solving, communicating the results and evaluation. The implementation of the OME AKE learning model in increasing student learning activeness is in children's learning being invited to do orientation or introduction to learning material, especially from the aspect of knowledge, after that children play a role according to their respective tasks, the children then analyze the material in detail, after the analysis is done then the results are conveyed to his friends in the form of presentations in groups and in class, the teacher then gives an evaluation of the process and results of the students. Students actively learn: such as paying attention (visual activities), listening, discussing, students 'readiness to ask questions, students' courage, listening and solving problems (mental activities).
\end{abstract}

Keywords: OME-AKE Learning Model in Increasing activity.

\section{A. Pendahuluan}

Pendidikan merupakan kebutuhan pokok bagi manusia, karena manusia disaat dilahirkan tidak mengetahui sesuatu apapun. Dalam 
pendididikan dikenal juga istilah pembelajaran. ${ }^{1}$ Proses belajar mengajar memerlukam model pembelajaran. Model pembelajaran merupakan salah satu aspek pembelajaran yang penting untuk mentransfer pengetahuan atau kebudayaan dari seorang guru kepada para pelajar, melalui model pembelajaran pembelajaran terjadi proses internalisasi dan pemilikan ilmu dari oleh pelajar. ${ }^{2}$

Mengajar sebenarnya bermaksud menyampaikan ilmu pengetahuan, meningkatkan keyakinan menambah nilai-nilai murni dan luhur kepada para pelajar yang belum mengetahui. ${ }^{3}$ Belajar mengajar merupakan kebutuhan yang mutlak dan sangat mendesak. Salah satu upaya untuk meningkatkan mutu kegiatan belajar mengajar dan hasil belajar adalah peningkatan mutu kemampuan profesionalime guru. Mutu kemampuan profesionalisme guru dapat dilihat dari kemampuannya membelajarkan para siswa dan mengelola kelas secara efektif dan efisien, sehingga para siswa mengusai bahan-bahan pelajaran yang diberikan sesuai dengan tuntutan kurikulum. ${ }^{4}$ Didalam pendidikan Islam, guru dituntut untuk memiliki profesionalisme. Hal tersebut sesuai dengan QS. Az-Zumar: 39. Ayat tersebut memperkuat betapa guru harus memiliki profesionalisme. Hal tersebut menjadikan tanggungjawab guru harus dimaksimalkan untuk membantu pemerintah dalam rangka mencerdaskan kehidupan bangsa.

Upaya mencerdaskan kehidupan bangsa dikelola secara sistematis oleh pemerintah melalui lembaga formal dan nonformal. Pemerintah dalam hal ini, menyelenggarakan satu sistem pendidikan Nasional yang tertuang dalam UUD 1945 (pasal 31 ayat 2) menyatakan "pemerintah mengusahakan dan menyelengarakan satu sistem pengajaran nasional, yang diatur dengan undang-undang". ${ }^{5}$ Upaya pemerintah tersebut diwujudkan dengan

${ }^{1}$ Ali Mustofa, Pendidikan Keagamaan Untuk Membentuk Kerukunan Antar Umat Beragama Di Medowo Kandangan Kediri, Nazhruna: Jurnal Pendidikan Islam Vol. 3 No 1 2020. 17. ISSN: 2614-8013. DOI: https://doi.org/10.31538/nzh.v3i1.399

${ }^{2}$ Asrohah.Konsep dan Model Pembelajaran Pembelajaran. (Jakarta : Renika cipta.1999) , 77.

${ }^{3}$ Ibid, 83.

${ }^{4}$ Musaheri, Pengembangan Kurikulum Pendidikan (Jakarta: Raja Gradindro Persada, 2006 )12.

${ }^{5}$ Sugiono, Metodologi Pendidikan (Jakarta: Bumi aksara, 2008 ) 43 
mengedepankan standarisasi mutu pendidikan dengan penyeragaman kurikulum secara nasional,

Proses belajar-mengajar dipengaruhi oleh buku dan guru, di pihak lain buku terhadap proses belajar-mengajar. Sedangkan syarat mutlak berlangsungnya proses belajar-mengajar. Maka, proses belajar-mengajar akan berlangsung baik jika ada guru, model pembelajaran dan buku ajar. ${ }^{6}$

Dalam kaitan tersebut, maka proses belajar-mengajar akan berjalan baik jika buku bacaan dimanfaatkan sebaik-baiknya. Model yang dipilih guru mampu memotivasi belajar anak. Tjokrowardoyo mengatakan, ada 10 segi didaktis yang harus diperhatikan guru dalam proses belajar mengajar. Kesepuluh didaktis tersebut dimaksudkan agar guru berhasil menyampaikan materi dengan baik, dan siswa mampu menerima dan mengembangkan materi ajar. Adapun kesepuluh segi dedaktis itu adalah: (1) menarik perhatian; (2) mendorong anak untuk belajar sendiri; (3) menyesuaikan dengan milliu; (4) mempergunakan yang mudah diketahui oleh anak; (5) diperagakan; (6) menghubung-hubungkan mata pelajaran; (7) memperbesar minat bekerja sama; (8) praktis; (9) mengingat jiwa perseoraan; dan (10) selalu diulangi.

Untuk memenuhi segi dedaktis pembelajaran di atas, guru harus mampu memilih yang sesuai dengan kondisi sekolah. Model pembelajaran $O M E-A K E$ merupakan model pembelajaran yang tepat untuk menggiring siswa mandiri, berkompetensi, bernalar, dan mampu mengembangkan materi pelajaran yang diberikan guru. Oleh karena itu model $O M E-A K E$ diambil dari singkatan kata-kata kunci pada sintaks yang digunakan dalam pembelajaran, yaitu orientasi, model, analisis, komunikasi, dan evaluasi.

Model OME-AKE ini terutama didasarkan kepada pendekatan pembelajaran kontekstual. Ada lima prinsip dasar pengembangan model pembelajaran ini, yakni berpusat kepada siswa, berdasarkan masalah, terintegrasi, berorientasi masyarakat, menawarkan pilihan, sistematis, dan berkelanjutan.

7. Achmad Ds.dkk. Kurikulum Berbasis Kompetensi. (Bandung:Remaja Rosda Karya,2002,93 
Adapun alasan penulis sangat tertarik melaksanakan penelitian di MTs. Al-Arief Jate Gili Genting Sumenep adalah lembaga tersebut menerapkan model OME AKE, peserta didik disana aktif dalam belajar, prestasi akademik dan non akademik peserta didik sangat bagus.

\section{B. Pembahasan}

\section{Model Pembelajaran OME AKE}

\section{a. Definisi Model Pembelajaran OME AKE}

Model pembelajaran OME AKE adalah singkatan dari orientasi, model, analisis, komunikasi dan evaluasi. Pengertian ini dilakukan karena perlunya dilakukan perubahan dalam peningkatan kreatifitas mengajar guru dalam melakukan pengelolaan dalam kegiatan belajar mengajar. Nama model ini diambil dari singkatan kata-kata kunci pada sintaks yang digunakan dalam pembelajaran, yaitu orientasi, model, eksplorasi, analisis, komunikasi, dan evaluasi. Pada kenyataanya model ini dapat pula digunakan untuk pembelajaran terpadu di kelas rendah atau untuk pembelajaran mata pelajaran lainnya. ${ }^{7}$

Model Ome-Ake ini terutama didasarkan pada pembelajaran kontekstual. Ada tujuh prinsip pengembangan model ini, yakni: berpusat pada siswa, berdasarkan masalah, terintegrasi, berorientasi masyarakat, menawarkan pilihan, sistematis dan berkelanjutan.

Prinsip berpusat pada siswa menempatkan siswa sebagai subjek belajar yang secara aktif membangun pemahaman dengan jalan merangkai pengalaman yang telah dimiliki dengan pengalaman baru yang ditemukan. Sebagai subjek, siswa diposisikan sebagai pusat kegiatan pembelajaran dalam arti sebagai pemegang sentral kemudi pembelajaran. Guru berposisi sebagai motivator, fasilitator, pendukung, dan pendamping siswa dalam belajar. ${ }^{8}$

${ }^{7}$ Sugiono, Metodelogi Pendidikan. (Jakarta: Bumi aksara,2008)76

${ }^{8}$ Ibid: 199 
Dalam prinsip berdasarkan masalah, kegiatan pembelajaran dimulai dari masalah-masalah nyata dalam kehidupan sehari yang actual, otentik, relevan, dan bermakna bagi siswa. Dengan pembelajaran yang dimulai dari masalah, siswa belajar suatu konsep/ teori dan prinsip sekaligus memecahkan masalah. Dengan demikian, sekurang- kurangnya ada dua hasil belajar yang dicapai, yaitu jawaban terhadap masalah (produk) dan cara memecahkan masalah (proses). Dalam hal ini kemampuan memecahkan merupakan hal yang penting yang bermakna bagi siswa dan bukan sekedar akumulasi pengetahuan dan teori karena merupakan cermin perkembangan kemampuan menyikapi masalah secara fleksibel (suatu strategi kognitif yang membantu mereka menganalisis situasi tidak terduga dan mampu menghasilkan solusi bermakna). ${ }^{9}$

Prinsip terintregasi didasarkan pada pemikiran bahwa pemebelajaran utuh dan bermakna bila ada hubungan antar disiplin ilmu dan pengembangan berbagai aspek hasil belajar. Sebagai contoh, pada saat siswa belajar aspek akademik, kepadanya juga dikembangkan aspek- aspek lainnya yang relevan, seperti aspek sosial dan sikap. Dalam prinsip ini bahasa memiliki peran sentral dalam perkembangan intelektual, sosial, dan emosional peserta didik dan merupakan penunjang keberhasilan dalam mempelajari semua bidang studi.

Prinsip berorientasi masyarakat diarahkan kepada upaya agar dalam pembelajaran siswa dapat dikondisikan dengan baik untuk dapat mengimplementasikan apa yang dipelajari didalam kelas ke dalam konteks masyarakat atau kebalikannya, yakni mengambil masalahmasalah yang ada dimasyarakat sebagai "bahan kajian" dalam pembelajaran di kelas.

Prinsip menawarkan pilihan dimaksudkan untuk memberikan perhatian pada keragaman karakteristik siswa, baik dari segi potensi akademik, gaya belajar, kecepatan belajar, kemampuan berkomunikasi,

${ }^{9}$ Abu Ahmad, Peng Media Pembelajaran .(Malang: Logos Wacana Ilmu, 2001), 154 
kondisi daerah, maupun jenjang serta jenis pendidikan, tanpa membedakan agama, suku, budaya, dan adapt istiadat, serta status sosial ekonomi dan gender. Hal itu tidak disikapi secara "sama rata", tetapi secara variatif. Atas dasar itu, pembelajaran tidak dirancang dan direalisasikan sesuai dengan keinginan guru, tetapi keinginan siswa. Pada satu sisi, kepada siswa ditawarkan banyak pilihan sesuai dengan karakteristik dan kebutuhan belajarnya, pada sisi lain tanggung jawab untuk belajar ditingkatkan melalui pemberian arahan dan motivasi konstruktif. ${ }^{10}$.

Model OME-AKE ini terutama didasarkan pada pendekatanpendekatan kontekstual. Ada tujuh prinsip dasar pengembangan model ini, yakni berpusat pada siswa, berdasarkan masalah, terintegrasi, berorientasi masyarakat, menawarkan pilihan, sistematis, dan berkelanjutan. Prinsip berpusat pada siswa menempatkan siswa sebagai subjek belajar yang secara aktif membangun pemahaman dengan jalan merangkai pengalaman baru yang ditemukan. Sebagai subjek, siswa diposisikan sebagai pusat kegiatan pembelajaran dalam arti sebagai pemegang sentral kemudi pembelajaran. Guru berposisi sebagai motivator, fasilitator, pendukung, dan pendamping siswa dalam belajar. $^{11}$

\section{b. Sintaks Model Pembelajaran OME AKE}

Model pembelajaran ini terdiri atas enam sintaks yang diuraikan sebagai berikut $:^{12}$

1) Orientasi Pembelajaran

Sintaks ini merupakan fase yang diisi dengan kegiatan pengondisian kelas, penyampaian tujuan, penganalisisan tujuan, pengaitan/hubungan materi sebelumnya dengan materi baru. Dengan demikian kreativitas guru berperan besar dalam sintaks ini.

${ }^{10}$ Mardalis,Model Pembelajaran,( Jakarta: Rinika Cipta,2009) 213

11 Ibid: 258

${ }^{12}$ Syamsudin, Model dan Strategi Pembelajaran, (Yogyakarta, Pustaka Pelajar, 2004), 245. 
Tujuan yang dirumuskan dalam standard kompetensi, kompetensi dasar, maupun indicator merupakan rumusan untuk orang tua (guru). Dalam sintaks ini guru dituntut dapat menyampaikan, menganalisis, dan mengaitkan materi yang akan diajarkan dengan materi sebelumnya secara pedagogis sehingga anak berada antara belajar dan bermain. Pada dasarnya, sasaran utama dari sintaks ini adalah aktivitas individual.

2) Pemodelan

Sintaks ini bertujuan mengenalkan kepada siswa model keterampilan berbahasa yang baik. Dari model tersebut siswa dapat melakukan penjiplakan (copying), pengadaptasian, baru kemudian mengembangkan keterampilan sendiri. Fase pemodelan dapat dilakukan dengan pemutaran kaset/CD/VCD, pendemonstrasian, penghadiran narasumber/praktisi/model, atau penganalisisan model. Sintaks ini menjadi sintaks utama dalam pembelajaran bahasa karena belajar bahasa adalah belajar keterampilan. Dalam belajar keterampilan, pemagangan melalui pengamatan dan penelaahan model merupakan langkah atau fase yang diyakini tepat, sintaks ini dapat dilakukan dengan cara individual maupun kelompok.

3) Eksplorasi Topik

Dalam sintaks ini guru berusaha mengajak siswa untuk mengenali sumber-sumber materi pembelajaran kemudian mengidentifikasikan batas-batas aspek kognitif, afektif, dan psikomotoriknya, serta menyeleksi materi yang utama dan yang tidak utama. Sintaks ini dapat dilakukan secara individual maupun kelompok. Baik secara individual maupun kelompok, langkah dalam sintaks ini dilakukan secara induktif. Sintaks ini hadir sebagai kebalikan dari langkah pembelajaran yang memulainya dari definisi. 
4) Analisis dan Pemecahan Masalah Topik

Pada sintaks ini siswa diajak untuk mengklasifikasikan topic, mencari bahan pemecahan topic, merumuskan pemecahan topic, dan menyusun laporan lisan maupun tertulis. Pelaksanaan fase ini amat disarankan dalam bentuk kerja kelompok terbimbing. Kelompok yang dapat dibentuk dalam fase ini adalah kelompok diskusi, kelompok pemeranan, maupun kelompok demonstrasi. Pembentukan kelompoknya pun disarankan bervariasi. Sebagaimana fase ekplorasi topic, fase ini menekankan pada pembelajaran yang bersifat induktif.

5) Pengomunikasian Hasil

Sintaks ini dapat dilakukan dengan pemaparan hasil secara lisan maupun pemajangan hasil secara tertulis. Aktivitas pemaparan hasil dapat dilakukan secara individual, misalnya melalui presentasi, demonstrasi, atau pameran, tetapi dapat juga dilakukan secara berkelompok, melalui bermain peran, presentasi kelompok, permainan, pameran atau demonstrasi.

6) Evaluasi/Refleksi

Sintaks ini berisi aktivitas penyimpulan materi pembelajaran, penyimpulan kegiatan pembelajaran, penganalisisan manfaat pembelajaran, penilaian kegiatan pembelajaran, penilaian hasil pembelajaran, penindaklanjutan kegiatan pembelajaran. Aktivitas evaluasi dan refleksi dapat dengan Tanya jawab, angket, tes, dan pengayaan, baik secara individual maupun kelompok. Yang paling lazim dalam aktivitas ini adalah klasikal.

\section{Keaktifan Belajar Peserta Didik}

\section{a.Pengertian Keaktifan belajar peserta didik}

Secara harfiah keaktifan berasal dari kata aktif yang berarti sibuk, giat (Kamus Besar Bahasa Indonesia: 17). Aktif mendapat 
awalan ke-dan -an, sehingga menjadi keaktifan yang mempunyai arti kegiatan atau kesibukan. Jadi, keaktifan belajar adalah kegiatan atau kesibukan peserta didik dalam kegiatan belajar mengajar di sekolah maupun di luar sekolah yang menunjang keberhasilan belajar siswa. ${ }^{13}$

Keaktifan tersebut tidak hanya keaktifan jasmani saja, melainkan juga keaktifan rohani. Menurut Sriyono keaktifan jasmani dan rohani yang dilakukan peserta didika dalam kegiatan belajar mengajar adalah sebagai berikut:

1) Keaktifan indera; pendengaran, penglihatan, peraba, dan sebagainya. Peserta didik harus dirangsang agar dapat menggunakan alat inderanya sebaik mungkin. Mendikte dan menyuru mereka menulis sepanjang jam pelajaran akan menjemukan. Demikian pula dengan menerangkan terus tanpa menulis sesuatu dipapan tulis. Maka pergantian dari membaca ke menulis, menulis ke menerangkan dan seterunya akan lebih menarik dan menyenangkan.

2) Keaktifan akal; akal peserta didik harus aktif atau dikatifkan untuk memecahkan masalah, menimbang, menyusun pendapat dan mengambil keputusan.

3) Keaktifan ingatan; pada saat proses belajar mengajar peserta didik harus aktif menerima bahan pelajaran yang disampaikan oleh guru, dan menyimpannya dalam otak. Kemudian pada suatu saat ia siap dan mampu mengutarakan kembali.

4) Keaktifan emosidalam hal ini peserta didik hendaklah senantiasa berusaha mencintai pelajarannya, karena dengan mencintai pelajarannya akan menambah hasil belajar peserta didik itu sendiri.

${ }^{13}$ Ibid, 233 
Sebenarnya semua proses belajar mengajar peserta didik mengandung unsur keaktifan, tetapi antara peserta didik yang satu dengan yang lainnya tidak sama. Oleh karena itu, peserta didik harus berpartisipasi aktif secara fisik dan mental dalam kegiatan belajar mengajar. Keaktifan peserta didik dalam proses belajar merupakan upaya peserta didik dalam memperoleh pengalaman belajar, yang mana keaktifan belajar peserta didik dapat ditempuh dengan upaya kegaiatan belajar kelompok maupun belajar secara perseorangan. ${ }^{14}$

\section{b. Jenis-Jenis Keaktifan Belajar}

Perbuatan belajar merupakan perbuatan yang sangat kompleks dan proses yang berlangsung pada otak manusia. Dengan melakukan perbuatan belajar tersebut peserta didik akan menjadi aktif di dalam kegiatan belajar Jenis-jenis keaktifan belajar siswa dalam proses belajar sangat beragam. Curiculum Guiding Commite of the Winsconsin Cooperative Educational Program dalam Oemar Hamalik (2009: 20-21) mengklasifikasikan aktivitas peserta didik dalam proses belajar menjadi: (1) kegiatan penyelidikan: membaca, berwawancara, mendengarkan radio, menonton film, dan alat-alat AVA lainnya; (2) kegiatan penyajian: laporan-laporan, panel and round table discussion, mempertunjukkan visual aid, membuat grafik dan chart; (3) kegiatan latihan mekanik: digunakan bila kelompok menemui kesulitan sehingga perlu diadakan ulangan dan latiha; (4) kegiatan apresiasi: mendengarkan musik, membaca, menyaksikan gambar; (5) kegiatan observasi dan mendengarkan: bentuk alat-alat dari murid sebagai alat bantu belajar; (6) kegiatan ekspresi kreatif: pekerjaan tangan, menggambar, menulis, bercerita, bermain, membuat sajak, bernyanyi, dan bermain musik, (7) bekerja dalam kelompok: latihan dalam tata kerja demokratis, pembagian kerja antara kelompok dalam melaksanakan rencana, (8) percobaan: belajar mencobakan cara-

\footnotetext{
${ }^{14}$ M, Nazir, Model Pembelajaran Penelitian. (Jakarta: Ghalia Indonesia 1998) 102
} 
cara menegrjakan sesuatu, kerja laboratorium dengan menekankan perlengkapan yang dapat dibuat oleh peserta didik di samping perlengkapan yang telah tersedia, serta (9) kegiatan mengirganisasi dan menilai: diskriminasi, menyeleksi, mengatur dan menilai pekerjaan yang dikerjakan oleh mereka sendiri. ${ }^{15}$

Lebih lanjut, Mohammad Ali membagi jenis keaktifan siswa dalam proses belajar ada delapan aktivitas, yaitu: mendengar, melihat, mencium, merasa, meraba, mengilah ide, menyatakan ide, dan melakukan latihan. Secara sederhana kedelapan aktivitas tersebut dapat dijelaskan sebagai berikut:

1) Mendengar, dalam proses belajar yang sangat menonjol adalah mendengar dan melihat. Apa yang kita dengar dapat menimbulkan tanggapan dalam ingatan-ingatan, yang turut dalam membentuk jiwa sesorang.

2) Melihat, peserta didik dapat mneyerap dan belajar $83 \%$ dari penglihatannya. Melihat berhubungan dengan penginderaan terhadap objek nyata, seperti peraga atau demonstrasi. Untuk meningkatkan keaktifan peserta didik dalam belajar melalui proses mendengar dan melihat, sering digunakan alat bantu dengar dan pandang, atau yang sering di kenal dengan istilah alat peraga.

3) Mencium, sebenarnya penginderaan dalam proses belajar bukan hanya mendengar dan melihat, tetapi meliputi penciuman. Seseorang dapat memahami perbedaan objek melalui bau yang dapat dicium.

4) Merasa, yang dapat memberi kesan sebagai dasar terjadinya berbagai bentuk perubahan bentuk tingkah laku bisa juga dirasakan dari benda yang dikecap.

5) Meraba, untuk melengkapi penginderaan, meraba dapat dilakukan untuk membedakan suatu benda dengan yang lainnya.

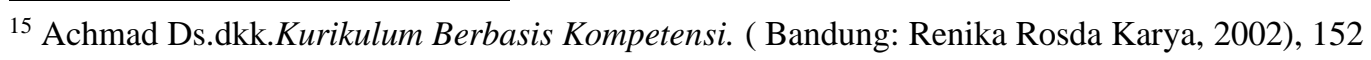


6) Mengolah ide, dalam mengolah ide peserta didik melakukan proses berpikir atau proses kognisi. Dari keterangan yang disampaikan kepadanya, baik secara lisan maupun secara tulisan, serta dari proses penginderaan yang lain yang kemudian peserta didik mempersepsi dan menanggapinya. Berdasarkan tanggapannya, dimungkinkan terbentuk pengetahuan, pemahaman, kemampuan menerapkan prinsip atau konsep, kemampuan menganalisis, menarik kesimpulan dan menilai. Inilah bentuk-bentuk perubahan tingkah laku kognitif yang dapat dicapai dalam proses belajar mengajar.

7) Menyatakan ide, tercapainya kemampuan melakukan proses berpikir yang kompleks ditunjang oleh kegiatan belajar melalui pernyataan atau mengekspresikan ide. Ekspresi ide ini dapat diwujudkan melalui kegiatan diskusi, melakukan eksperimen, atau melalui proses penemuan melalui kegiatan semacam itu, taraf kemmapuan kognitif yang dicapai lebih baik dan lebih tinggi dibandingkan dengan hanya sekedar melakukan penginderaan, apalagi penginderaan yang dilakukan hanya sekedar mendengar semata-mata.

8) Melakukan latihan: bentuk tingkah laku yang sepatutnya dapat dicapai melalui proses belajar, di samping tingkah laku kognitif, tingkah laku afektif (sikap) dan tingkah laku psikomotorik (keterampilan). Untuk meningkatkan keterampilan tersebut memerlukan latihan-latihan tertentu. Oleh karena itu kegiatan proses belajar yang tujuannya untuk membentuk tingkah laku psikomotorik dapat dicapai dengan melalui latihan-latihan.

Berdasarkan beberapa pendapat di atas, maka dapat disimpulkan bahwa jenis-jenis kegiatan keaktifan peserta didik dalam proses belajar dapat dikelompokkan menjadi keaktifan jasmani dan keaktifan rohani, di 
mana bentuk dari kedua jenis keaktifan tersebut sangat beragam, diantaranya adalah: keaktifan panca indera, akal, ingatan, dan emosional. ${ }^{16}$

\section{Analisis}

\section{Langkah-langkah Implementasi Model Pembelajaran OME AKE dalam Peningkatan Keaktifan Belajar.}

Model pembelajaran berorientasi pada guru menekankan pada bagaimana proses guru dalam mengajar. Yang menjadi titik acuan bagi guru adalah ketercapaian target kurikulum. ${ }^{17}$ Pemikiran guru dalam pembelajaran adalah bagaimana menyajikan informasi belajar kepada peserta didik. Bagaimana peserta didik menguasai materi pelajaran dengan baik melalui tindakan guru diruang kelas. Dalam hal ini guru memegang peranan penting sebagai pemberi informasi yang harus dikuasai oleh peserta didik. Pendekatan pembelajaran berorientasi pada siswa memandang peserta didik sebagai objek sekaligus subjek yang belajar. Kepentingan pembelajaran bertumpu pada proses belajar siswa, dimana peserta didik dituntut untuk aktif dalam pembelajaran. ${ }^{18}$

Model pembelajaran OME AKE memang merupakan cara yang paling jitu dan lebih berpengaruh pada hasil. Artinya dengan menggunakan model pembelajaran OME AKE sangat besar kemungkinan akan berhasil apa yang diharapkan oleh seorang pendidik, karena para peserta didik lebih banyak meniru apa yang dilihat oleh mereka dari apa yang didenger oleh mereka. Apa yang disampaikan oleh pendidik belum tentu diamalkan dalam waktu yang singkat oleh peserta didik, berbeda dengan apa yang diperbuat atau dilakukan oleh pendidik, maka hal itu secara singkat para peserta didik akan menirunya. Hal ini perlu

\footnotetext{
${ }^{16}$ Abu Ahmad,Peng Media Pembelajaran( Malang:Logos Wacana Ilmu, 2001) 188

${ }^{17}$ Ibid, 124

${ }^{18}$ Ibid, 121
} 
dilaksanakan dengan sungguh-sungguh, agar tujuan pendidikan, yaitu terbentuknya akhlak yang mulia akan tercapai.

Model OME-AKE ini terutama didasarkan pada pendekatanpendekatan kontekstual. Ada tujuh prinsip dasar pengembangan model ini, yakni berpusat pada siswa, berdasarkan masalah, terintegrasi, berorientasi masyarakat, menawarkan pilihan, sistematis, dan berkelanjutan. Prinsip berpusat pada siswa menempatkan siswa sebagai subjek belajar yang secara aktif membangun pemahaman dengan jalan merangkai pengalaman baru yang ditemukan. Sebagai subjek, siswa diposisikan sebagai pusat kegiatan pembelajaran dalam arti sebagai pemegang sentral kemudi pembelajaran. Guru berposisi sebagai motivator, fasilitator, pendukung, dan pendamping siswa dalam belajar.

Penerapan model pembelajaran ini terdiri atas enam sintaks yang diuraikan sebagai berikut ${ }^{19}$

a. Orientasi Pembelajaran

Sintaks ini merupakan fase yang diisi dengan kegiatan pengondisian kelas, penyampaian tujuan, penganalisisan tujuan, pengaitan/hubungan materi sebelumnya dengan materi baru. Dengan demikian kreativitas guru berperan besar dalam sintaks ini. Tujuan yang dirumuskan dalam standard kompetensi, kompetensi dasar, maupun indicator merupakan rumusan untuk orang tua (guru). Dalam sintaks ini guru dituntut dapat menyampaikan, menganalisis, dan mengaitkan materi yang akan diajarkan dengan materi sebelumnya secara pedagogis sehingga anak berada antara belajar dan bermain. Pada dasarnya, sasaran utama dari sintaks ini adalah aktivitas individual.

b. Pemodelan

${ }^{19}$ Syamsudin, Model dan Strategi Pembelajaran, (Yogyakarta, Pustaka Pelajar, 2004), 245. 
Sintaks ini bertujuan mengenalkan kepada siswa model keterampilan berbahasa yang baik. Dari model tersebut siswa dapat melakukan penjiplakan (copying), pengadaptasian, baru kemudian mengembangkan keterampilan sendiri. Fase pemodelan dapat dilakukan dengan pemutaran kaset/CD/VCD, pendemonstrasian, penghadiran narasumber/praktisi/model, atau penganalisisan model. Sintaks ini menjadi sintaks utama dalam pembelajaran bahasa karena belajar bahasa adalah belajar keterampilan. Dalam belajar keterampilan, pemagangan melalui pengamatan dan penelaahan model merupakan langkah atau fase yang diyakini tepat, sintaks ini dapat dilakukan dengan cara individual maupun kelompok.

c. Eksplorasi Topik

Dalam sintaks ini guru berusaha mengajak siswa untuk mengenali sumber-sumber materi pembelajaran kemudian mengidentifikasikan batas-batas aspek kognitif, afektif, dan psikomotoriknya, serta menyeleksi materi yang utama dan yang tidak utama. Sintaks ini dapat dilakukan secara individual maupun kelompok. Baik secara individual maupun kelompok, langkah dalam sintaks ini dilakukan secara induktif. Sintaks ini hadir sebagai kebalikan dari langkah pembelajaran yang memulainya dari definisi.

d. Analisis dan Pemecahan Masalah Topik

Pada sintaks ini siswa diajak untuk mengklasifikasikan topic, mencari bahan pemecahan topic, merumuskan pemecahan topic, dan menyusun laporan lisan maupun tertulis. Pelaksanaan fase ini amat disarankan dalam bentuk kerja kelompok terbimbing. Kelompok yang dapat dibentuk dalam fase ini adalah kelompok diskusi, kelompok pemeranan, maupun kelompok demonstrasi. Pembentukan kelompoknya pun disarankan bervariasi. Sebagaimana fase ekplorasi topic, fase ini menekankan pada pembelajaran yang bersifat induktif. 


\section{e. Pengkomunikasian Hasil}

Sintaks ini dapat dilakukan dengan pemaparan hasil secara lisan maupun pemajangan hasil secara tertulis. Aktivitas pemaparan hasil dapat dilakukan secara individual, misalnya melalui presentasi, demonstrasi, atau pameran, tetapi dapat juga dilakukan secara berkelompok, melalui bermain peran, presentasi kelompok, permainan, pameran atau demonstrasi.

\section{f. Evaluasi/Refleksi}

Sintaks ini berisi aktivitas penyimpulan materi pembelajaran, penyimpulan kegiatan pembelajaran, penganalisisan manfaat pembelajaran, penilaian kegiatan pembelajaran, penilaian hasil pembelajaran, penindaklanjutan kegiatan pembelajaran. Aktivitas evaluasi dan refleksi dapat dengan Tanya jawab, angket, tes, dan pengayaan, baik secara individual maupun kelompok. Yang paling lazim dalam aktivitas ini adalah klasikal.

Pelaksanaan model pembelajaran OME AKE dalam peningkatan keaktifan belajar peserta didik. Salah satu lembaga pendidikan Islam yang menerapkan model pembelajaran OME AKE dalam peningkatan keaktifan belajar peserta didik adalah MTs. Al- Arief Jate- Gili genting- Sumenep. Lembaga ini merupakan lembaga pendidikan yang bermuansa dan berbasis Islam, sehingga dalam pelaksanaan model pembelajaran OME AKE dalam peningkatan keaktifan belajar peserta didiknya juga tidak jauh dari konsep dan prinsip yang diajarkan oleh Islam itu sendiri. Adapun pelaksanaan model pembelajaran OME AKE dalam peningkatan keaktifan belajar peserta didik adalah dalam pembelajaran anak diajak untuk melakukan orientasi atau pengenalan terhadap materi pembelajaran terutama dari aspek pengetahuan, setelah itu anak memainkan peran sesuai tugasnya masing-masing, anak-anak kemudian menganalisis materi secara detail, setelah analisis dilakukan kemudian hasilnya disampaikan kepada teman- 
temannya dalam bentuk presentasi dikelompok maupun di kelas, guru kemudian memberikan evaluasi terhadap proses dan hasil yang dilakukan siswa.

Langkah-langkahnya yang pertama orientasi: yakni dengan kegiatan pengondisian kelas, penyampaian tujuan, penganalisisan tujuan, pengaitan/hubungan materi sebelumnya dengan materi baru. Berikutnya pemodelan yakni mengenalkan kepada siswa model keterampilan tertentu yang baik. Dari model tersebut siswa dapat melakukan penjiplakan (copying), pengadaptasian, baru kemudian mengembangkan keterampilan sendiri. Fase pemodelan dapat dilakukan dengan pemutaran kaset/CD/VCD,pendemonstrasian,penghadiran dalam pelaksanaan narasumber /praktisi/model, atau penganalisisan model. Berikutnya eksplorasi topik yakni dengan mengajak siswa untuk mengenali sumbersumber materi pembelajaran kemudian mengidentifikasikan batas-batas aspek kognitif, afektif, dan psikomotoriknya, serta menyeleksi materi yang utama dan yang tidak utama. Selanjutnya analisis dan pemecahan masalah topik yakni siswa diajak untuk mengklasifikasikan topik, mencari bahan pemecahan topik, merumuskan pemecahan topik, dan menyusun laporan lisan maupun tertulis. Pelaksanaan fase ini amat disarankan dalam bentuk kerja kelompok terbimbing. Kelompok yang dapat dibentuk dalam fase ini adalah kelompok diskusi, kelompok pemeranan, maupun kelompok demonstrasi. Pembentukan kelompoknya pun disarankan bervariasi. Berikutnya pengomunikasian hasil yakni dengan pemaparan hasil secara lisan maupun pemajangan hasil secara tertulis. Aktivitas pemaparan hasil dapat dilakukan secara individual, misalnya melalui presentasi, demonstrasi, atau pameran, tetapi dapat juga dilakukan secara berkelompok, melalui bermain peran, presentasi kelompok, permainan, pameran atau demonstrasi. Yang terakhir evaluasi/refleksi dengan aktivitas penyimpulan materi pembelajaran, penyimpulan kegiatan pembelajaran, penganalisisan manfaat pembelajaran, penilaian kegiatan pembelajaran, penilaian hasil pembelajaran, penindaklanjutan kegiatan pembelajaran. 
Aktivitas evaluasi dan refleksi dapat dengan Tanya jawab, angket, tes, dan pengayaan, baik secara individual maupun kelompok. Yang paling lazim dalam aktivitas ini adalah klasikal.

Berdasarkan analisis pengataman peneliti di lapangan memang para peserta didiknya sudah banyak yang mengalami perubahan dari sisi koginitif dan afektif. Kemampuan memahami materi meningkat, hal tersebut mendorong para peserta didik aktif dalam belajar. Dampak dari keaktifan peserta didik melalui model Ome Ake inilah pembelajaran yang dilakukan menjadi efektif dan menyenangkan.

\section{Keaktifan Belajar Peserta Didik di MTs. Al-Arief Jate- Gili- Genting- Sumenep Madura}

Belajar adalah berbuat, oleh karena itu tidak ada belajar tanpa aktifitas. Pengalaman belajar hanya dapat diperoleh jika siswa aktif beriteraksi dengan lingkungannya. Seorang guru dapat menyajikan dan menyediakan bahan pelajar, tapi siswalah yang mengolah dan mencernanya sendiri sesuai kemauan, kemampuan, bakat, dan latar belakangnya. Keaktifan siswa penting dalam proses pembelajaran sebab pengetahuan, keterampilan dan sikap tidak dapat ditransfer begitu saja tetapi harus siswa sendiri yang mengelolahnya terlebih dahulu.

Keaktifan Proses pembelajaran pada hakekatnya juga untuk mengembangkan aktivitas dan kreatifitas peserta didik melalui berbagai interaksi dan pengalaman belajar. Keaktifan belajar siswa merupakan unsur dasar yang penting bagi keberhasilan proses pembelajaran. Keaktifan adalah kegiatan yang bersifat fisik maupun mental, yaitu berbuat dan berfikir sebagai suatu rangkaian yang tidak dapat dipisahkan Belajar yang berhasil harus melalui berbagai macam aktifitas, baik aktifitas fisik maupun psikis. Aktifitas fisik merupakan suatu bentuk bahwa siswa giat aktif dengan anggota badan, membuat sesuatu, bermain maupun bekerja, ia tidak hanya duduk dan mendengarkan, melihat atau 
hanya pasif. Siswa yang memiliki aktifitas psikis (kejiwaan) adalah jika daya jiwanya bekerja sebanyak-banyaknya atau banyak berfungsi dalam rangka pembelajaran. Keaktifan siswa dalam kegiatan belajar tidak lain adalah untuk mengkonstruksi pengetahuan mereka sendiri. Mereka aktif membangun pemahaman atas persoalan atau segala sesuatu yang mereka hadapi dalam proses pembelajaran.

Aktivitas siswa tidak hanya mendengarkan dan mencatat seperti yang lazim terdapat di sekolah - sekolah tradisonal, sebagaimana Nana Sudjana menyatakan keaktifan belajar siswa dapat dilihat dalam hal: (1) turut serta dalam melaksanakan tugas belajarnya; (2) terlibat dalam pemecahan masalah; (3) Bertanya kepada siswa lain atau guru apabila tidak memahami persoalan yang dihadapinya; (4) Berusaha mencari berbagai informasi yang diperlukan untuk pemecahan masalah;(5) Melaksanakan diskusi kelompok sesuai dengan petunjuk guru;(6) Menilai kemampuan dirinya dan hasil- hasil yang diperolehnya; (7) Melatih diri dalam memecahkan soal atau masalah yang sejenis. Berdasarkan uraian di atas dapat disimpulkan keaktifan siswa dapat dilihat dari berbagai hal seperti memperhatikan (visual activities), mendengarkan, berdiskusi, kesiapan siswa bertanya, keberanian siswa, mendengarkan,memecahkan soal (mental activities).

Sebagaimana teori tentang keaktifan belajar peserta didik diatas, peneliti menemukan adanya keaktifan belajar peserta didik di MTs. AlArief Jate- Gili- Genting- Sumenep Madura. Dimana sesorang siswa mengikuti dan sangat aktif mengikuti pembelajaran didalam kelas, hal ini dibuktikan dengan ketika salah satu dari peserta didik kurang memahami penjelasan dari bapak ibu guru, ia langsung mengacungkan tangan dan meminta bapak ibu guru untuk mengulangi penjelasan yang belum dipahami. Selain itu ketika ada masalah dalam pemecahan masalah tugas kelompok mereka aktif mengikuti sesuai dengan petunjuk bapak ibu guru, 
saling memberi masukan dengan temannya dan kerjasama untuk menyelesaikan tugas kelompok tersebut.

Jadi dapat disimpulkan bahwa proses pembelajaran di MTs AlArief Jate Gili Genting Sumenep Madura, Termasuk pembelajaran yang aktif, dimana peserta didik dengan pendidik ada hubungan timbal balik dalam proses pembelajaran.

\section{Penutup}

Langkah-langkah Implementasi model pembelajaran OME AKE dalam peningkatan keaktifan belajar peserta didik di MTs Al-arief Jate- Gili genting-Sumenep berjalan sesuai dengan standar proses pendidikan. Dalam pembelajaran mengacu pada sintaks yang ditetapkan, dengan langkahlangkahnya yang pertama orientasi: yakni dengan kegiatan pengondisian kelas, penyampaian tujuan, penganalisisan tujuan, pengaitan/hubungan materi sebelumnya dengan materi baru. Berikutnya pemodelan yakni mengenalkan kepada siswa model keterampilan tertentu yang baik. Dari model tersebut siswa dapat melakukan penjiplakan (copying), pengadaptasian, baru kemudian mengembangkan keterampilan sendiri. Fase pemodelan dapat dilakukan dengan pemutaran kaset/CD/VCD, pendemonstrasian, penghadiran narasumber /praktisi/model, atau penganalisisan model. Berikutnya eksplorasi topik yakni dengan mengajak siswa untuk mengenali sumbersumber materi pembelajaran kemudian mengidentifikasikan batas-batas aspek kognitif, afektif, dan psikomotoriknya, serta menyeleksi materi yang utama dan yang tidak utama. Selanjutnya analisis dan pemecahan masalah topik yakni siswa diajak untuk mengklasifikasikan topik, mencari bahanbahan pemecahan topik, merumuskan pemecahan topik, dan menyusun laporan lisan maupun tertulis. Pelaksanaan fase ini amat disarankan dalam bentuk kerja kelompok terbimbing. Kelompok yang dapat dibentuk dalam fase ini adalah kelompok diskusi, kelompok pemeranan, maupun kelompok demonstrasi. Pembentukan kelompoknya pun disarankan bervariasi. Berikutnya pengomunikasian hasil yakni dengan pemaparan hasil secara lisan 
maupun pemajangan hasil secara tertulis. Aktivitas pemaparan hasil dapat dilakukan secara individual, misalnya melalui presentasi, demonstrasi, atau pameran, tetapi dapat juga dilakukan secara berkelompok, melalui bermain peran, presentasi kelompok, permainan, pameran atau demonstrasi. Yang terakhir evaluasi/refleksi dengan aktivitas penyimpulan materi pembelajaran, penyimpulan kegiatan pembelajaran, penganalisisan manfaat pembelajaran, penilaian kegiatan pembelajaran, penilaian hasil pembelajaran, penindaklanjutan kegiatan pembelajaran. Aktivitas evaluasi dan refleksi dapat dengan Tanya jawab, angket, tes, dan pengayaan, baik secara individual maupun kelompok. Yang paling lazim dalam aktivitas ini adalah klasikal.

Peserta didik di MTs al Arif aktif dalam berbagai bentuk keaktifan belajar, seperti memperhatikan (visual activities), mendengarkan, berdiskusi, kesiapan siswa bertanya, keberanian siswa, mendengarkan,memecahkan soal (mental activities). Peserta didik mengikuti dan sangat aktif mengikuti pembelajaran didalam kelas,

\section{BIBLIOGRAPHY}

Asrohah. Konsep dan Model Pembelajaran Pembelajaran. Jakarta: Renika cipta. 1999.

Musaheri, Pengembangan Kurikulum Pendidikan (Jakarta: Raja Gradindro Persada, 2006.

Syamil Qur'an, al Qur'an Terjemah tafsir Perkata. Bandung: Sigma Iksamedia, 2010.

Sugiono, Metodologi Pendidikan. Jakarta: Bumi aksara, 2008.

Achmad Ds.dkk. Kurikulum Berbasis Kompetensi. Bandung:Remaja Rosda Karya,2002.

Ahmad, Abu, Peng Media Pembelajaran. Malang: Logos Wacana Ilmu, 2001.

Mardalis, Model Pembelajaran, Jakarta: Rinika Cipta,2009. 
Mustofa, Ali, Pendidikan Keagamaan Untuk Membentuk Kerukunan Antar Umat Beragama Di Medowo Kandangan Kediri, Nazhruna: Jurnal Pendidikan Islam Vol. 3 No 1 2020. Hal. 17. ISSN: 2614-8013. DOI:

https://doi.org/10.31538/nzh.v3i1.399

Syamsudin, Model dan Strategi Pembelajaran, Yogyakarta, Pustaka Pelajar, 2004.

M, Nazir, Model Pembelajaran Penelitian. Jakarta: Ghalia Indonesia 1998. 